\title{
Kinerja Keuangan, Tipe Industri dan Sustaiability Report
}

\section{Komang Alda Cika Arisandi ${ }^{1}$ \\ Fakultas Ekonomi dan Bisnis \\ Universitas Udayana, Indonesia}

\author{
Ni Putu Sri Harta Mimba2 \\ Fakultas Ekonomi dan Bisnis \\ Universitas Udayana, Indonesia
}

Surel: alda.cika85@gmail.com

\section{ABSTRAK}

Banyaknya isu kerusakan lingkungan akibat aktivitas perusahaan menjadikan sustainability report penting untuk diungkapkan. Pengungkapan sustainability report dapat menjelaskan bagaimana perusahaan mengelola masalah sosial dan lingkungan yang ditimbulkan. Tujuan penelitian ini adalah untuk mengetahui pengaruh kinerja keuangan, yang diproksikan oleh profitabilitas, likuiditas, dan leverage serta pengaruh tipe industri pada pengungkapan sustainability report. Penelitian ini dilakukan pada perusahaan yang menjadi pemenang asia sustainability reporting rating tahun 2017-2019. Sampel dalam penelitian ini berjumlah 16 perusahaan, dengan menggunakan teknik purposive sampling. Metode analisis yang digunakan adalah analisis linier berganda. Dari hasil analisis diperoleh bahwa profitabilitas, likuiditas, dan tipe industri berpengaruh signifikan terhadap pengungkapan sustainability report. Sedangkan leverage tidak berpengaruh signifikan terhadap pengungkapan sustainability report.

Kata Kunci: Profitabilitas; Likuiditas; Leverage; Tipe Industri; ASRRAT.

\section{Financial Performance, Industry Type and Sustainability Report}

\section{ABSTRACT}

The number of issues of environmental damage due to company activities makes the sustainability report important to disclose. Disclosure of sustainability reports can explain how the company manages the social and environmental problems it causes. The purpose of this study was to determine the effect of financial performance, which is proxied by profitability, liquidity, and leverage as well as the effect of industry type on the disclosure of the sustainability report. This research was conducted on companies thatwon the Asia Sustainability Reporting Rating in 20172019. The sample in this study amounted to 16 companies, using purposive sampling technique. The analytical method used is multiple linear analysis. From the results of the analysis, it is found that profitability, liquidity, and type of industry have a significant effect on the disclosure of the sustainability report. Meanwhile, leverage has no significanteffect on the disclosure of the sustainability report.

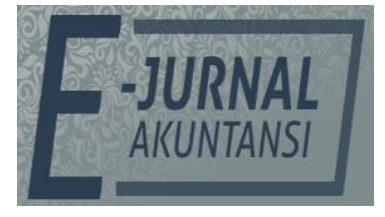

e-ISSN 2302-8556

Vol. 31 No. 11

Denpasar, November 2021

Hal. 2736-2747

DOI:

10.24843/EJA.2021.v31.i11.p05

PENGUTIPAN:

Arisandi, K. A. C., \& Mimba, N. P.S. H. (2021). Kinerja Keuangan, Tipe Industri dan Sustaiability Report. E-Jurnal Akuntansi, 31(11), 2736-2747

RIWAYAT ARTIKEL:

Artikel Masuk: 2 Februari 2021 Artikel Diterima: 29 Maret 2021

Keywords: Profitability; Liquidity; Leverage; Industry Type; ASRRAT.

Artikel dapat diakses: https:/ / ojs.unud.ac.id/index.php/Akuntansi/index 


\section{PENDAHULUAN}

Banyaknya isu kerusakan lingkungan akibat aktivitas perusahaan seperti, kerusakan lingkungan akibat limbah batubara di sepanjang daerah aliran sungai air bengkulu, adanya lubang bekas tambang yang tidak direklamasi, hingga pembuangan limbah migas ke perairan Karawang (Ambari, 2019). Dikutip dari Segger (2003), Hal ini membuat berubahnya pandangan bisnis dari single P (profit) menjadi triple bottom line (profit, planet, people). Sejauh mana perusahaan melaksanakan prinsip triple bottom line dapat dilihat dari sustainability report perusahaan. Sustainability reporting adalah informasi keuangan dan non keuangan yang bermanfaat bagi para pemangku kepentingan mengenai kegiatan ekonomi, sosial dan lingkungan yang dijalankan perusahaan. Sebagai bentuk apresiasi National Center for Sustainability reporting (NCSR) memberikan penghargaan kepada perusahaan yang melakukan pengungkapan sustainability report dalam ajang Asia Sustainability reporting Rating (ASRRAT).

Ajang ASRRAT diharapkan dapat mendorong perusahaan lain untuk melakukan pengungkapan sustainability report. Dikutip dari Kencana (2019), pengungkapan sustainability report di Indonesia masih tergolong rendah. Hal ini dapat terlihat pada data tahun 2019 jumlah perusahaan yang menerbitkan sustainability report hanya sebanyak 110 perusahaan dari total 629 perusahaan yang tercatat di Bursa Efek Indonesia. Padahal sustainability report merupakan bentuk komitmen perusahaan kepada masyarakat dan lingkungan di sekitar perusahaan (Fitri \& Yuliandari, 2018). A pabila diabaikan akan mengganggu keberlangsungan perusahaan. Dikutip dari Dilling (2010), terdapat beberapa faktor yang memengaruhi pengungkapan sustainability report, yaitu kinerja keuangan dan tipe industri. Dalam penelitian ini kinerja keuangan diproksikan oleh profitabilitas, likuiditas, dan leverage.

Dibia \& Onwuchekwa (2015), Kouloukoui et al. (2019), Nazari et al. (2015), Putri \& Elma (2019), Kansal et al. (2014), Skouloudis et al. (2014), Dominik \& Sassen (2016), Karlina et al. (2019), Liana (2019), Fitri \& Yuliandari (2018), Jannah \& Kurnia (2016), Ahmad (2014), Rahman (2017) mengatakan, perusahaan yang memiliki profitabilitas yang tinggi menggambarkan perusahaan tersebut memiliki keuangan yang lebih untuk melakukan pelaporan sukarela yang lebih baik dimana profitabilitas berpengaruh terhadap pengungkapan sustainability report. Namun (Karaman et al., 2018), (Syakirli et al., 2019), dan (Nasution et al., 2018) memperoleh hasil profitabilitas tidak berpengaruh pada pengungkapan sustainability report.

Modugu (2020) menyatakan bahwa perusahaan likuid cenderung mengungkapkan masalah keberlanjutan untuk membuktikan kemampuannya dalam memenuhi kebutuhan jangka pendek yang jatuh tempo dan masih tetap menjalankan operasional yang optimal. Penelitian lainnya yang sejalan dengan penelitian tersebut yaitu (Fitri \& Yuliandari, 2018), (Jannah \& Kurnia, 2016), dan (Ruhana \& Hidayah, 2020) yang menyatakan bahwa likuiditas berpengaruh pada pengungkapan sustainability report. Namun bertolak belakang dengan hasil penelitian yang dilakukan oleh (Nasution et al., 2018) yang dilakukan pada seluruh bank yang terdaftar dalam BEI.

Sejalan dengan Afsari et al., (2017), semakin tinggi tingkat leverage perusahaan, semakin besar kemungkinan perusahaan untuk menekan biaya, salah 
satunya biaya pengungkapan sustainability report. Hal ini menunjukkan bahwa leverage berpengaruh negatif signifikan terhadap pengungkapan sustainability report. Penelitian lainnya yang sejalan dengan penelitian tersebut yaitu (Liana, 2019), (Beelde \& Tuybens, 2015), serta (Nasution et al., 2018). Namun bertolak belakang dengan hasil penelitian yang dilakukan oleh (Masum et al., 2020) dan (Fitri \& Yuliandari, 2018).

Selain kinerja keuangan, tipe industri dapat berpengaruh pada pengungkapan sustainability report (Dilling, 2010). Dikutip dari Ahmad (2014), tipe industri dalam penelitian ini dibedakan menjadi dua jenis, yaitu indutri high profile dan low profile. Tipe industri yang dikaji oleh Ahmad (2014) menjelaskan bahwa industri yang termasuk dalam kelompok industri high profile, yaitu industri yang bergerak di bidang migas, pertambangan, kertas, agrobisnis, dan telekomunikasi. Alasan pemilihan industri tersebut adalah perusahaan-perusahaan tersebut merupakan regulated company. Sedangkan yang termasuk dalam industri low profile, yaitu industri yang bergerak di bidang properti, keuangan dan perbankan, supplier peralatan medis, retailer, tekstil, produk personal dan produk rumah tangga.

Menurut Welbeck et al., (2017) industri high profile menghadapi tekanan sosial yang lebih besar karena efek dari aktivitas operasinya bersinggungan dengan masyarakat dan lingkungan luas. Oleh sebab itu perusahaan mengungkapkan sustainability report lebih banyak untuk memuaskan para pemangku kepentingan. Dengan demikian industri high profile mengungkapkan lebih banyak sustainability report dibandingkan low profile. Beberapa penelitian yang sejalan dengan hasil tersebut yaitu (Ahmad, 2014), (Fortunella \& Hadiprajitno, 2015), (Branco et al., 2014), (Faisal et al., 2012), dan (Modugu, 2020) Namun bertolak belakang dengan (Agnes \& Hartomo, 2018).

Berdasarkan latar belakang di atas, mengenai banyaknya isu kerusakan lingkungan serta dampak negatif yang ditimbulkan dari kegiatan perusahaan, sedikitnya perusahaan yang mengungkapkan sustainability report, dan hasil penelitian yang masih inkonsisten. Maka dari itu peneliti mengangkat penelitian mengenai pengaruh kinerja keuangan dan tipe industri pada pengungkapan sustainability report. Terdapat perbedaan dengan penelitian sebelumnya yaitu dari segi variabel, sampel, dan waktu penelitian. Variabel yang diadopsi yaitu profitabilitas, likuiditas, leverage, tipe industri. Sedangkan sampel penelitian digunakan adalah perusahaan yang masuk dalam daftar pemenang Asia Sustainability reporting Rating tahun 2017-2019.

Menurut (Haniffa \& Cooke, 2005), Teori legitimasi menjelaskan bahwa perusahaan memiliki kontrak dengan masyarakat untuk melakukan kegiatan berdasarkan nilai-nilai justice, dan bagaimana perusahaan menanggapi berbagai kelompok kepentingan untuk melegitimasi tindakan perusahaan, perusahaan menggunakan pengungkapan keberlanjutan untuk meningkatkan persepsi publik tentang keberlanjutan perusahaan. Dikutip dari, Kouloukoui et al. (2019) “Ketika ada perbedaan antara nilai yang dianut perusahaan dengan nilai di masyarakat, maka pada saat itu legitimasi perusahaan akan terancam, perbedaan yang terjadi ini dinamakan legitimacy gap dan pabila diabaikan oleh perusahaan hal ini dapat mempengaruhi perusahaan dalam kemampuannya untuk melanjutkan kegiatan 
usahanya." Oleh sebab itu penting bagi perusahaan untuk mengungkapkan sustainability report dalam menajaga keberlangsungan perusahaan.

Meek et al. (1995) menyebutkan dalam teori stakeholder, direktur dan manajer harus dapat memenuhi harapan semua stakeholder, bukan hanya pemilik perusahaan saja. menyatakan bahwa kelangsungan hidup perusahaan pada dukungan stakeholder, untuk mendapatkan dukungan dari para stakeholder perusahaan menerbitkan berbagai jenis laporan, salah satunya yaitu sustainability report. Karena melalui pengungkapan sustainability report perusahaan bisa menampilkan informasi yang lengkap berkaitan dengan kegiatan dan pengaruhnya terhadap kondisi sosial dan lingkungan masyarakat.

Karaman et al. (2018) menyebutkan, rasio profitabilitas adalah kemampuan perusahaan memperoleh laba dalam hubungannya dengan penjualan, total aktiva maupun modal sendiri dimana semakin tinggi rasio profitabilitas, maka semakin tinggi pula informasi yang diberikan oleh manajer karena pihak manajemen ingin meyakinkan investor mengenai profitabilitas dan kompetensi manajer. Selain itu perusahaan juga ingin mendapatkan dan mempertahankan dukungan yang diperoleh dari para stakeholder. $\mathrm{H}_{1}$ : Profitabilitas berpengaruh positif pada pengungkapan sustainability report.

Likuiditas adalah kemampuan perusahaan untuk memenuhi kewajiban jangka pendek. Perusahaan yang memiliki tingkat likuiditas yang tinggi berusaha untuk memberikan informasi yang luas tentang kinerja keuangan, untuk meningkatkan citra perusahaan. Salah satu pengungkapan tersebut adalah sustainability report yang merupakan suatu bentuk laporan tanggung jawab sosial dan lingkungan yang juga mengungkapkan mengenai kinerja keuangan perusahaan.

$\mathrm{H}_{2}$ : Likuiditas berpengaruh positif pada pengungkapan sustainability report.

Leverage merupakan rasio yang digunakan untuk mengetahui sejauh mana kemampuan perusahaan dalam menggunakan hutang untuk pembiayaan operasional perusahaan. Perusahan dengan tingkat leverage yang tinggi cenderung akan menekan biaya-biayanya termasuk biaya untuk mengungkapkan sustainability report. Oleh sebab itu perusahaan dengan leverage yang tinggi akan mengungkapkan sustainability report lebih rendah.

$\mathrm{H}_{3}$ : Leverage berpengaruh negatif pada pengungkapan sustainability report.

Tipe industri adalah suatu karakteristik perusahaan berupa ruang lingkup operasi perusahaan yang dijalankan. Tipe industri dikelompokkan menjadi dua, yaitu high profile dan low profile. Tipe industri high profile merupakan perusahaan yang mempunyai tingkat sensitivitas yang tinggi terhadap lingkungan. Sedangkan tipe ind ustri low profile merupakan perusahaan yang memiliki dampak atau sensitivitas yang lebih rendah terhadap lingkungan. Oleh sebab itu industri yang masuk kategori high profile cenderung melakukan lebih banyak pengungkapan pada sustainability report dibandingkan perusahaan yang masuk kategori low profile.

$\mathrm{H}_{4}$ : Tipe industri high profile lebih banyak melakukan pengungkapan sustainability report dibandingkan tipe industri low profile. 


\section{METODE PENELITIAN}

Penelitian ini dilakukan pada perusahaan-perusahaan yang menang pada ajang Asia Sustainability reporting Rating (ASRRAT) tahun 2017-2019. Penelitian ini menggunakan data sekunder, berupa laporan keuangan dan sustainability reporting perusahaan yang memenangkan ASRRAT tahun 2017-2019. Sampelyang digunakan dalam penelitian ini adalah perusahaan yang berhasil menang dalam Asia Sustainability reporting Rating (ASRRAT) tahun 2017-2019.

Penentuan sampel menggunakan teknik purposive sampling, dengan kriteria sebagai berikut: 1) perusahaan yang memenangkan Asia Sustainability reporting Rating (ASRRAT) tahun 2017-2019, 2) perusahaan-perusahaan yang menerbitkan sustainability report berturut-turut tahun 2017-2019, 3) perusahaanperusahaan non-keuangan yang terdaftar di BEI. Dari kriteria sampel yang telah ditentukan, terdapat 16 perusahaan yang memenuhi kriteria. Variabel terikat berupa sustainability report yang diukur menggunakan metode content analysis. Variabel bebas berupa profitabilitas yang diukur menggunakan rasio return on asset, likuiditas yang diukur menggunakan rasio current ratio, leverage yang diukur menggunakan rasio debt ratio, dan tipe ind ustri yang diukur menggunakan variabel dummy. Teknik analisis yang digunakan adalah analisis linier berganda dengan bantuan program SPSS.

\section{HASIL DAN PEMBAHASAN}

Jumlah data dalam penelitian sebanyak 48, diperoleh dari jumlah data laporan keuangan dan sustainability report selama 3 periode yaitu 2017-2019.

Tabel 1. Hasil Uji Statistik Deskriptif

\begin{tabular}{lccccc}
\hline \multicolumn{1}{c}{ Variabel } & $\mathrm{N}$ & Minimum & Maximum & Mean & Std.Deviation \\
\hline Sustainabilityreport & 48 & 0,13 & 0,99 & 0,384 & 0,224 \\
Profitabilitas & 48 & $-18,15$ & 18,60 & 3,064 & 5,925 \\
Likuiditas & 48 & 22,29 & 461,76 & 182,320 & 105,131 \\
Leverage & 48 & 14,47 & 1190,90 & 189,409 & 228,663 \\
Tipe_Industri & 48 & 0,00 & 1,00 & 0,480 & 0,434 \\
\hline
\end{tabular}

Sumber: Data Penelitian, 2020

Bedasarkan hasil uji statistik deskriptif, Sustainability report, memperoleh nilai minimum sebesar 0,13 sedangkan nilai maximum sebesar 0,99 , memiliki nilai rata-rata sebesar 0,384 dengan standar deviasi sebesar 0,224 . Variabel profitabilitas memiliki nilai minimum sebesar $-18,15$, nilai maximum sebesar 18,60 , dan nilai ratarata sebesar 3,064 dengan standar deviasi sebesar 5,925. Variabel likuiditas memperoleh nilai minimum sebesar 22,29, nilai maximum sebesar 461,76, memiliki nilai rata-rata sebesar 182,320 dengan standar deviasi sebesar 105,131. Variabel leverage memiliki nilai minimum sebesar 14,47 , sedangkan nilai maximum diperoleh sebesar 1190,90, memiliki nilai rata-rata sebesar 189,409 dengan standar deviasi sebesar 228,663. Variabel tipe industri memiliki nilai minimum sebesar 0,00 dan nilai maximum sebesar 1 , sedangkan nilai rata-rata sebesar 0,480 dengan standar deviasi sebesar 0,434 . 
Tabel 2. Hasil Uji Normalitas

\begin{tabular}{llc}
\hline & & Unstandardized Residual \\
\hline $\mathrm{N}$ & & 48 \\
Normal Parametersa, & Mean & 0,086 \\
& Std.Deviation & 0,738 \\
Most Extreme Differences & Absolute & 0,090 \\
& Positive & 0,090 \\
& Negative & $-0,057$ \\
Test Statistic & & 0,621 \\
Asymp.Sig.(2-tailed) & & 0,835 \\
\hline
\end{tabular}

Sumber: Data Penelitian, 2020

Hasil uji normalitas menunjukkan, nilai Asymp. Sig (2-tailed) 0,835 lebih besar dari level of significant, yaitu 5 persen $(0,05)$. Jadi dapat disimpulkan bahwa nilai residual pada model regresi yang diuji sudah berdistribusi normal.

Tabel 3. Hasil Uji Autokorelasi

\begin{tabular}{|c|c|c|c|c|c|}
\hline Model & $\mathrm{R}$ & R Square & $\begin{array}{c}\text { Adjusted } R \\
\text { Square }\end{array}$ & Std. Error of the Estimate & Durbin-Watson \\
\hline
\end{tabular}

\begin{tabular}{|c|c|c|c|c|}
\hline 1 & $0823 \mathrm{a}$ & 18 & 090 & 17 \\
\hline
\end{tabular}

Sumber: Data Penelitian, 2020

Hasil uji autokorelasi menunjukkan nilai DW sebesar 1,730 nilai ini lebih besar dari nilai du 1,7206. Maka dapat disimpulkan bahwa data sudah lolos uji autokorelasi.

Tabel 4. Hasil Uji Multikolinearitas

\begin{tabular}{lll}
\hline Variabel & Tolerance & VIF \\
\hline Profitabilitas $\left(\mathrm{X}_{1}\right)$ & 0,643 & 1,555 \\
Likuiditas $\left(\mathrm{X}_{2}\right)$ & 0,518 & 1,929 \\
Leverage $(\mathrm{X3})$ & 0,926 & 1,079 \\
Tipeindustri $(\mathrm{X} 4)$ & 0,799 & 1,252 \\
\hline
\end{tabular}

Sumber: Data Penelitian, 2020

Berdasarkan hasil uji multikolinearitas, nilai Tolerance yang lebih dari 0,1 (10 persen) ataupun nilai VIF yang kurang dari 10. Berdasarkan nilai Tolerance dan VIF, maka tidak ditemukan adanya gejala multikolinearitas.

Tabel 5. Hasil Uji Heteroskedastisitas

\begin{tabular}{lccccc}
\hline \multirow{2}{*}{ Model } & \multicolumn{2}{c}{$\begin{array}{c}\text { Unstandardized } \\
\text { Coefficients }\end{array}$} & $\begin{array}{c}\text { Standardized } \\
\text { Coefficients }\end{array}$ & \multirow{2}{*}{$\mathrm{t}$} & \multirow{2}{*}{ Sig. } \\
\cline { 2 - 4 } & $\mathrm{B}$ & Std. Error & Beta & & \\
\hline 1. (Constant) & 0,614 & 0,076 & & 8,097 & 0,000 \\
Profitabilitas & $-0,092$ & 0,081 & $-0,212$ & $-1,136$ & 0,262 \\
Likuiditas & 0,110 & 0,157 & 0,147 & 0,704 & 0,485 \\
Leverage & $-0,007$ & 0,102 & $-0,011$ & $-0,071$ & 0,944 \\
TipeIndustri & 0,015 & 0,075 & 0,035 & 0,207 & 0,837 \\
\hline
\end{tabular}

Sumber: Data Penelitian, 2020

Hasil uji heteroskedastisitas menunjukkan, nilai signifikansi Profitabilitas $\left(X_{1}\right)$ sebesar 0,262 , Likuiditas $\left(X_{2}\right)$ sebesar 0,485 , Leverage $\left(X_{3}\right)$ sebesar 0,944 dan Tipe industri $(X 4)$ sebesar 0,837 . Hasil uji tersebut memiliki nilai yang lebih besar dari $\alpha=0,05$. Oleh karena itu, dapat disimpulkan bahwa tidak terjadi heteroskedastisitas. 
Tabel 6. Rangkuman Hasil Analisis Regresi Linear Berganda

\begin{tabular}{lccccc}
\hline \multirow{2}{*}{ Model } & \multicolumn{2}{c}{$\begin{array}{c}\text { Unstandardized } \\
\text { Coefficients }\end{array}$} & $\begin{array}{c}\text { Standardized } \\
\text { Coefficients }\end{array}$ & $\mathrm{t}$ & \multirow{2}{*}{ Sig. } \\
\cline { 2 - 4 } & $\mathrm{B}$ & Std. Error & Beta & & \\
\hline (Constant) & 0,193 & 0,081 & & 2,382 & 0,022 \\
Profitabilitas $\left(\mathrm{X}_{1}\right)$ & 0,336 & 0,087 & 0,418 & 3,870 & 0,000 \\
Likuiditas $\left(\mathrm{X}_{2}\right)$ & 0,354 & 0,168 & 0,254 & 2,114 & 0,040 \\
Leverage $\left(\mathrm{X}_{3}\right)$ & $-0,092$ & 0,109 & $-0,076$ & $-0,843$ & 0,404 \\
Tipe industri $(\mathrm{X} 4)$ & 0,337 & 0,080 & 0,409 & 4,225 & 0,000 \\
- Adjusted $R$ Square: & 0,647 & & & & \\
F count & 22,573 & & & & \\
- F Sig & 0,000 & & & &
\end{tabular}

Sumber: Data Penelitian, 2020

Hasil uji koefisien determinasi memperoleh, adjusted $\mathrm{R}^{2}$ (koefisien determinasi yang telah disesuaikan) adalah sebesar 0,647. Ini berarti sebesar 64,7 persen variasi Sustainability report dapat dipengaruhi secara signifikan oleh variabel Profitabilitas $\left(X_{1}\right)$, Likuiditas $\left(X_{2}\right)$, Leverage $\left(X_{3}\right)$, dan Tipe industri $\left(X_{4}\right)$ sedangkan sisanya sebesar 35,3 persen dijelaskan oleh faktor-faktor lain. Hasil uii $\mathrm{F}$ (F test) menunjukkan, nilai $\mathrm{F}$ hitung sebesar 22,573 dengan nilai signifikansi $\mathrm{P}$ value 0,000 yang lebih kecil dari $\alpha=0,05$, ini berarti model yang digunakan pada penelitian ini adalah layak. Hasil ini memberikan makna bahwa ketiga variabel independen mampu memprediksi atau menjelaskan fenomena sustainability report. Hal ini berarti secara simultan profitabilitas $\left(X_{1}\right)$, likuiditas $\left(X_{2}\right)$, leverage $\left(X_{3}\right)$ dan tipe industri $\left(\mathrm{X}_{4}\right)$ berpengaruh signifikan terhadap sustainability report.

Berdasarkan hasil uji t, diperoleh nilai 0,00, nilai ini berada di bawah taraf signifikansi sebesar 0,05 , maka $\mathrm{H}_{1}$ diterima. Pada hasil analisis statistik terdapat 38 persen perusahaan yang memiliki tingkat profitabilitas di atas rata-rata diikuti dengan tingkat pengungkapan sustainability report di atas rata-rata. Hal ini menggambarkan bahwa 38 persen perusahaan dapat mengelola aset dengan baik, sehingga perusahaan memperoleh laba yang tinggi. Hasil penelitian ini sesuai dengan hasil penelitian yang dilakukan oleh (Kouloukoui et al., 2019), (Nazari et al., 2015), (Dibia \& Onwuchekwa, 2015), (Putri \& Elma, 2019), (Kansal et al., 2014), (Skouloudis et al., 2014), (Branco et al., 2014), (Dominik \& Sassen, 2016), (Karlina et al., 2019), (Liana, 2019), (Fitri \& Yuliandari, 2018), (Jannah \& Kurnia, 2016), (Ahmad, 2014), dan (Rahman, 2017) yang menyatakan profitabilitas memiliki pengaruh signifikan terhadap sustainability report. Sebab perusahaan yang memiliki tingkat profitabilitas yang tinggi dianggap memiliki sumber daya keuangan yang lebih besar untuk melakukan pengungkapan sukarela, sehingga mampu untuk melakukan pengungkapan sustainability report yang lebih baik.

Pada hasil uji $\mathrm{t}_{2}$ diperoleh nilai 0,04, nilai ini berada di bawah taraf signifikan 0,05, maka $\mathrm{H}_{2}$ diterima. Pada hasil analisis statistik terdapat 50 persen perusahaan yang memiliki tingkat likuiditas di atas rata-rata diikuti dengan tingkat pengungkapan sustainability report di atas rata-rata. Hal ini menggambarkan bahwa 50 persen perusahaan dapat mengelola aset dengan baik, sehingga perusahaan mampu untuk memenuhi kewajiban jangka pendeknya tepat waktu. Hasil penelitian ini sejalan dengan penelitian yang dilakukan oleh (Fitri \& Yuliandari, 2018), (Jannah \& Kurnia, 2016), (Ruhana \& Hidayah, 2020), dan 
(Modugu, 2020) yang menyatakan bahwa likuiditas berpengaruh pada pengungkapan sustainability report. Hal ini menunjukkan bahwa perusahaan yang memiliki tingkat likuiditas yang tinggi akan mendorong perusahaan dalam mengungkapkan lebih banyak informasi untuk meyakinkan stakeholder dengan mengungkapkan kegiatan berkaitan dengan sosial dan lingkungan melalui sustainability report.

Berdasarkan hasil uji t $\mathrm{H}_{3}$ diperoleh nilai 0,404, nilai ini berada di atas taraf signifikan 5 persen atau 0,05, maka $_{3}$ ditolak. Hasil penelitian ini sejalan dengan penelitian yang dilakukan oleh (Fitri \& Yuliandari, 2018), (Jannah \& Kurnia, 2016), (Putri \& Elma, 2019), (Nazari et al., 2015), (Kuzey \& Uyar, 2017), (Masum et al., 2020), (Dibia \& Onwuchekwa, 2015). Hasil ini menunjukkan bahwa leverage tidak berpengaruh pada pengungkapan sustainability report. Artinya perusahaan yang memiliki tingkat leverage yang tinggi tetap mengungkapkan sustainability report yang banyak. Karena, perusahaan merasa perlu untuk mengungkapkan tambahan informasi seperti informasi mengenai aktivitas sosial dan lingkungan perusahaan yang diungkapkan dalam sustainability report untuk meningkatkan kepercayaan calon kreditor dalam memberikan kredit kepada perusahaan.

Berdasarkan hasil uji $t$ diperoleh nilai 0,00 , nilai ini di bawah taraf signifikan 5 persen atau 0,05, maka $\mathrm{H}_{4}$ diterima. Pada uji $\mathrm{t}$ diketahui bahwa industri high profile mengungkapkan sustainability report lebih luas sebesar 33,7 persen dibandingkan industri low profile. Pada hasil analisis statistik terdapat 52 persen industri high profile yang melakukan pengungkapan sustainability report di atas rata-rata. Terdapat 25 persen industri low profile yang melakukan pengungkapan sustainability report di atas rata-rata. Perbedaan topik yang diungkapkan dapat dilihat, dimana industri high profile lebih banyak mengungkapkan pada topik lingkungan dan sosial, karena dalam aktivitas operasionalnya memiliki dampak terhadap lingkungan dan sosial yang lebih luas. Industri low profile lebih banyak mengungkapkan pada topik ekonomi dan sosial. Hasil penelitian ini sejalan dengan penelitian yang dilakukan oleh (Ahmad, 2014), (Fortunella \& Hadiprajitno, 2015), (Karlina et al., 2019), (Kouloukoui et al., 2019), (Adiatma, 2018), (Welbeck et al., 2017), (Kuzey \& Uyar, 2017), (Branco et al., 2014), (Faisal et al., 2012), dan (Modugu, 2020) yang menyatakan, tipe industri high profile lebih banyak melakukan pengungkapan sustainability report dibandingkan industri low profile. Karena, Industri high profile memiliki aktivitas operasi yang lebih berisiko untuk masyarakat dan lingkungan dibandingkan industri low profile.

\section{SIMPULAN}

Berdasarkan hasil analisis data maka dapat ditarik kesimpulan, profitabilitas berpengaruh pada pengungkapan sustainability report. Hal ini menunjukkan semakin tinggi tingkat profitabilitas perusahaan akan semakin mendorong perusahaan untuk mengungkapkan sustainability report lebih banyak. Likuiditas berpengaruh pada pengungkapan sustainability report. Hal ini menunjukkan bahwa semakin tinggi tingkat likuidtas suatu perusahaan maka, semakin tinggi pula sustainability report yang diungkapkan perusahaan. Leverage tidak berpengaruh pada pengungkapan sustainability report. Hal ini menunjukkan bahwa semakin tinggi tingkat leverage suatu perusahaan tidak membuat 
perusahaan untuk mengungkapkan sustainability report yang rendah. Sebab perusahaan mengungkapkan tambahan informasi seperti sustainability report untuk meningkatkan kepercayaan kreditor dalam memberikan kredit kepada perusahaan. Tipe industri high profile lebih banyak mengungkapkan sustainability report dibandingkan tipe industri low profile, maka hipotesis keempat dalam penelitian diterima. Hal ini menunjukkan bahwa perusahaan yang masuk kategori high profile melakukan pengungkapan sustainability report lebih banyak. Karena memiliki aktivitas operasi yang lebih berisiko untuk masyarakat dan lingkungan.

Keterbatasan dalam penelitian ini adalah sedikitnya jumlah sampel penelitian, yaitu hanya perusahaan non-keuangan yang masuk dalam pemenang ASRRAT. Saran yang dapat diberikan dalam penelitian ini adalah bagi perusahaan yang masuk kategori high profile, namun masih mengungkapkan sustainability report di bawah rata-rata untuk dapat meningkatkan pengungkapan sustainability report, khususnya pada topik ekonomi mengenai indikator anti-persaingan guna untuk mempertahankan legitimasi perusahaan, sehingga perusahaan dapat mempertahankan keberlangsungan dalam menjalankan operasinya. Sedangkan saran untuk penelitian selanjutnya adalah dapat melakukan penelitian pada sektor perbankan, sebab dalam penelitian ini sektor perbankan dikecualikan karena adanya perbedaan kinerja keuangan antara sektor perbankan dengan lainnya. Selain itu, sesuai peraturan POJK 51 sektor perbankan wajib menyusun laporan keberlanjutan.

\section{REFERENSI}

Adiatma, K. B. (2018). Pengaruh Tipe Industri, Kepemilikan Saham Pemerintah, Profitabilitas Terhadap Sustainability report. E-Jurnal Akuntansi Universitas Udayana, 25 , 934-958. https:/ / doi.org/https:// doi.org/10.24843/EJA.2018.v25.i02.p05

Afsari, R., Purnamawati, I. G. A., \& Prayudi, M. A. (2017). Pengaruh Leverage, Ukuran Perusahaan, Komite Audit dan Kepemilikan Institusional Terhadap Luas Pengungkapan Sustainability report (Studi Empiris Perusahaan yang Mengikuti ISRA Periode 2013-2015). E-Jurnal S1 AK Universitas Pendidikan Gannesha, 8(2), 1-12.

Agnes, P. A., \& Hartomo, O. D. (2018). Analysis Of Key Factors Affecting The Reporting Disclosure Indexes Of Sustainability reporting In Indonesia. International Journal of Business, Economic and Law, 16(1), 15-25.

Ahmad, F. (2014). Pengaruh Karakteristik Perusahaan Dan Profitabilitas Terhadap Pengungkapan Sustainability report (Studi Empiris Perusahaan yang Terdaftar Di BEI Periode 2009-2012). E-Journal Universitas Negeri Padang, 1-28. http:/ / ejournal.unp.ac.id/ students/index.php/akt/article/view/1552/117 5

Ambari, M. (2019). Begini Nasib Buruk Masyarakat Pesisir akibat Tumpahan Minyak di Karawang. MOngabay. https:/ / www.mongabay.co.id/ 2019/07/29/ begini-nasib-burukmasyarakat-pesisir-akibat-tumpahan-minyak-di-karawang.

Branco, M. C., Delgado, C., Gomes, S. F., \& Eugénio, T. C. P. (2014). Factors influencing the assurance of sustainability reports in the context of the economic crisis in Portugal. Managerial Auditing Journal, 29(3), 237-252. 
https: / / doi.org/10.1108/MAJ-07-2013-0905

De Beelde, I., \& Tuybens, S. (2015). Enhancing the credibility of reporting on corporate social responsibility in Europe. Business Strategy and the Environment, 24(3), 190-216. https:// doi.org/10.1002/bse.1814

Dibia, N. O., \& Onwuchekwa, J. C. (2015). Determinants of Environmental Disclosures in Nigeria: A Case Study of Oil and Gas Companies. International Journal of Finance and Accounting, 4(3), 145-152. https:/ / doi.org/10.5923/j.ijfa.20150403.01

Dilling, P. F. A. (2010). Sustainability reporting In A Global Context: What Are The Characteristics Of Corporations That Provide High Quality Sustainability reports An Empirical Analysis. International Business \& Economics Research Journal (IBER), 9(1), 19-30. https://doi.org/10.19030/iber.v9i1.505

Dominik, D. R., \& Sassen, J. F. (2016). What are the drivers of sustainability reporting? A systematic review. Sustainability Accounting, Management and Policy Journal, 7(2), 1-49. https:/ / doi.org/http:// dx.doi.org/10.1108/SAMPJ-08-2014-0050

Faisal, F., Tower, G., \& Rusmin, R. (2012). Legitimising Corporate Sustainability reporting Throughout the World. Australasian Accounting Business $\mathcal{E}$ Finance Journal, $6(2)$ 19-34. http://ro.uow.edu.au/aabfj/vol6/iss2/3/?utm_source=ro.uow.edu.au\%2F aabfj $\% 2$ Fvol6\%2Fiss2\%2F3\&utm_medium=PDF\&utm_campaign=PDFCove rPages

Fitri, A. A., \& Yuliandari, W. S. (2018). Pengaruh Kinerja Keuangan Terhadap Pengungkapan Sustainability report (Studi Kasus pada Perusahaan yang Terdaftar di Bursa Efek Indonesia Tahun 2014-2016). E-Proceeding of Management, 5(2), 2218-2226.

Fortunella, A. P., \& Hadiprajitno, B. (2015). the Effects of Corporate Governance Structure and Firm Characteristic Towards Environmental Disclosure. Diponegoro Journal of Accounting, 4(2), 717-727.

Haniffa, R. M., \& Cooke, T. E. (2005). The impact of culture and governance on corporate social reporting. Journal of Accounting and Public Policy, 24(5), 391430. https:/ / doi.org/10.1016/j.jaccpubpol.2005.06.001

Jannah, U. A. R., \& Kurnia. (2016). Pengaruh Kinerja Keuangan Terhadap Pengungkapan Sustainability report Pada Perusahaan Di Bei. Jurnal Ilmu Dan Riset Akuntansi, 5(2), 1-15.

Kansal, M., Joshi, M., \& Batra, G. S. (2014). Determinants of corporate social responsibility disclosures: Evidence from India. Advances in Accounting, 30(1), 217-229. https:/ / doi.org/10.1016/j.adiac.2014.03.009

Karaman, A. S., Kilic, M., \& Uyar, A. (2018). Sustainability reporting in the aviation industry: worldwide evidence. Sustainability Accounting, Management and Policy Journal, 9(4), 362-391. https:/ / doi.org/10.1108/SAMPJ-12-2017-0150

Karlina, W., Mulyati, S., \& Putri, T. E. (2019). the Effect of Company'S Size, Industrial Type, Profitability, and Leverage To Sustainability report Disclosure (Case Study On Companies Registered In Sustainability reporting Award (SRA) Period 2014-2016). JASS (Journal of Accounting for Sustainable Society), 1(1), 32. https:// doi.org/10.35310/jass.v1i01.68

Kencana, M. R. B. (2019). BEI Dorong Perusahaan Tercatat Terapkan 
Pembangunan Berkelanjutan. Liputan 6. https:/ / www.liputan6.com/bisnis/read/3950084/bei-dorong-perusahaantercatat-terapkan-pembangunan-berkelanjutan

Kouloukoui, D., Sant' Anna, Â. M. O., da Silva Gomes, S. M., de Oliveira Marinho, M. M., de Jong, P., Kiperstok, A., \& Torres, E. A. (2019). Factors influencing the level of environmental disclosures in sustainability reports: Case of climate risk disclosure by Brazilian companies. Corporate Social Responsibility and Environmental Management, 26(4), 791-804. https:// doi.org/10.1002/csr.1721

Kuzey, C., \& Uyar, A. (2017). Determinants of sustainability reporting and its impact on firm value: Evidence from the emerging market of Turkey. Journal of Cleaner Production, 143, 27-39. https:/ /doi.org/10.1016/j.jclepro.2016.12.153

Liana, S. (2019). Pengaruh Profitabilitas, Leverage, Ukuran Perusahaan dan Dewan Komisaris Independen terhadap Pengungkapan Sustainability report. Jesya (Jurnal Ekonomi E Ekonomi Syariah), 2(2), 199-208. https:// doi.org/10.36778/jesya.v2i269

Masum, M. H., Hasan, Mohammad Tariq Mahadi, H. M. M., Kashedul, W. T., \& Chowdhury, A. H. M. Y. (2020). Factors Affecting the Sustainability reporting, Evidence from Bangladesh. International Journal of Mechanical and Production Engineering Research and Development, 10(3), 8323-8338. https:/ / doi.org/10.24247/ijmperdjun2020792

Meek, G. K., Roberts, C. B., \& Gray, S. J. (1995). Factors Influencing Voluntary Annual Report Disclosures By U.S., U.K. and Continental European Multinational Corporations. Journal of International Business Studies, 26(3), 555-572. https:/ / doi.org/10.1057/palgrave.jibs.8490186

Modugu, K. P. (2020). Do corporate characteristics improve sustainability disclosure? Evidence from the UAE. International Journal of Business Performance Management, 21(1-2), 39-54. https:/ / doi.org/10.1504/IJBPM.2020.106106

Nasution, A. H., Erlina, \& Tamizi, H. . (2018). An Analysis on Influence of Profitability, Firm Size, Liquidity, and Leverage on the Expression of Firm's Social Responsibility in Banking Companies Listed in BEI (Indonesian Stock Exchange). International Journal of Research \& Review, 5(9), 92-105. www.ijrrjournal.com

Nazari, J. A., Herremans, I. M., \& Warsame, H. A. (2015). Sustainability reporting: External motivators and internal facilitators. Corporate Governance (Bingley), 15(3), 375-390. https:// doi.org/10.1108/CG-01-2014-0003

Putri, K. A., \& Elma, M. A. N. (2019). Pengaruh Profitabilitas, Likuiditas, dan Leverage terhadap Pengungkapan CorporateSocial Responsibility (CSR) pada Perusahaan Pertambangan yang Terdaftar di Bursa Efek Indonesia Tahun 2014 - 2017. Journal of Chemical Information and Modeling, 21(2), Profitabilitas, Leverage,Pengungkapan CSR. https:/ / repository.widyatama.ac.id/ xmlui/ bitstream/handle/123456789/5 525/ Bab 2.pdf?sequence $=10$ \&isAllowed $=y$

Rahman, A. R. (2017). Pengaruh Kinerja Keuangan dan Karakteristik Perusahaan Terhadap Pengungkapan Sustainability report pada Perusahaan Yang Listing di Bursa Efek Indonesia Tahun 2013-2015. JOM Fekom, 4(2), 4882-4895.

Ruhana, A., \& Hidayah, N. (2020). The Effect of Liquidity, Firm Size, and Corporate 
Governance Toward Sustainability report Disclosures (Survey on: Indonesia Sustainability report Award Participant). 120(Icmeb 2019), 279-284. https:/ / doi.org/10.2991/aebmr.k.200205.048

Segger, M. C. C. (2003). Sustainability and corporate accountability regimes: Implementing the Johannesburg Summit Agenda. Review of European Community and International Environmental Law, 12(3), 295-309. https:// doi.org/10.1111/1467-9388.00371

Skouloudis, A., Jones, N., Malesios, C., \& Evangelinos, K. (2014). Trends and determinants of corporate non-financial disclosure in Greece. Journal of Cleaner Production, 68, 174-188. https:/ / doi.org/10.1016/j.jclepro.2013.12.048

Syakirli, I., Charoline, C., \& Halmawati. (2019). Pengaruh Karakteristik Perusahaan Terhadap Pengungkapan Sustainability reporting. Jurnal Eksplorasi Akuntansi, 1(1), 277-289. https:// doi.org/2656-3649

Welbeck, E. E., Owusu, G. M. Y., Bekoe, R. A., \& Kusi, J. A. (2017). Determinants of environmental disclosures of listed firms in Ghana. International Journal of Corporate Social Responsibility, 2(1). https:/ / doi.org/10.1186/s40991-017-0023$\mathrm{y}$ 